\title{
DECLINING LABOUR SHARE OF INCOME IN SOUTH AfRICA: THE KaLMAN FILTER APPROACH
}

\author{
Irrshad Kaseeram* \\ University of Kwazulu-Natal \\ Ikaseeram@unizul.ac.za
}

Received: February 2014

\author{
Darma Mahadea" \\ University of Kwazulu-Natal \\ MahadeaD@ukzn.ac.za
}

Accepted: December 2014

\begin{abstract}
Recent research has shown that in both developed and emerging market economies, the labour share of national income has exhibited a declining trend since the 1980s. Research investigating the problem of high unemployment in the South African economy has inferred that this problem arises partly because of past and current socio-political conditions, low rates of economic growth, labour market rigidities, globalisation and institutional arrangements. As the labour absorption capacity is rather low, many people are unable to earn an income from an engagement in the formal labour market. This is likely to have implications for the relative distribution share of labour and capital in the country's national income. However, no recent published research has investigated this phenomenon in the South African context. Thus, this paper attempts to shed some light on the problem. Using yearly data from 1946 to 2013, the study employs the Kalman filter methodology within the standard Cobb-Douglas production function framework to investigate how labour and capital shares as well as total factor productivity have been behaving in this period. The results indicate that the share of total income going to labour has decreased over the long run, while that of capital has increased. Specifically, the share of capital increased from $3.1 \%$ in 1980 to $12 \%$ in 2013 , while that of labour decreased from $91 \%$ to $83 \%$. This reflects a rising income inequality and concentration of wealth, with output and income generation shifting to technological- or capital intensive production requiring more skilled labour, a trend also observed in certain other countries.
\end{abstract}

\section{Keywords}

Labour, capital, income inequality, income distribution, unemployment, economic growth, total factor productivity

*Prof I Kaseeram is a lecturer in Department of Economics, University of Zululand, South Africa.

\#Prof D Mahadea is a lecturer in the Department of Economics, University of KwaZulu-Natal (UKZN), South Africa. 


\section{INTRODUCTION}

In the process of producing national output, income is generated and distributed among the factors of production for their respective services in the value-adding production process. Wages go to labour and profits go the capital resource owners.

The International Labour Organization (ILO, 2013) asserts that the income share of labour is falling worldwide, thereby exacerbating inequality and poverty. The $0 \varepsilon C D$ (2012) study noted that during the past three decades, the share of national income represented by wages, salaries and benefits - the labour share - has declined in nearly all OECD countries, where the labour share fell from $66 \%$ to $62 \%$ of national output over the period 1990-2009. In the USA this drop was $4.5 \%$, if the top $1 \%$ earners are excluded. According to ILO's World of Work Report (2011), this decline seems more pronounced in developing and emerging countries, including China, that have in recent times registered high levels of economic growth. In the case of developed countries, such as those in the $\varepsilon U$, the USA and the UK, the profit share in national income has increased by $10 \%$, while that of labour has decreased by about the same proportion. The ILO report (2013) indicates that not all categories of labour have experienced this shrinking share; it is the low-skilled labour that seems to have been more adversely affected.

In the case of South Africa this shrinking share of labour in GDP is a course for concern, as the country is already experiencing high levels of unemployment, poverty and inequality. The rising income inequality, as indicated by the Gini coefficient, has increased from 0.57 in 1992 to 0.63 in 2009 , reflecting that ownership and control of capital and land, and the consequent returns, are much more concentrated than the third factor of production, labour, leading to social anger among the poor (The Economist, 2012). This experience of shrinking distributive share is contrary to the traditional Cobb-Douglas theoretical conception of a constant labour and capital share returns to fixed capital investment - of national income. The literature identifies factors such as increased productivity and capital-deepening, increased domestic and international competition, the reduction of workers' bargaining power (excluding South Africa), the evolution of collective bargaining institutions and financialisation as the main culprits in the labour share decline (Karabarbounis \& Nieman, 2013; 0ECD, 2012).

Not much research has been done in this area of changing factor contribution to output in South Africa. It is to be expected that as an economy develops the share of labour and capital would change, in response to changes in factor prices and employment conditions, depending on the elasticity of substitution and nature of technological progress. Accordingly, this paper attempts to quantify the behaviour of labour and capital shares of income in South Africa using the Kalman filter approach applied to long-term time series data covering the period 1946-2013. The paper consists of four sections. The first covers both the international and South African literature reviews on labour's share of income. This is followed by a brief outline of the CobbDouglas production model and its transformations to make it statistically analysable. Thereafter the results are presented and discussed. The final section contains the conclusion, which outlines policy implications. 


\section{THEORETICAL PERSPECTIVES ON UNEMPLOYMENT AND LABOUR SHARE OF INCOME}

National income is the value added to output by factors of production. According to the classical theory of distribution, inputs are rewarded according to their respective marginal productivity. When all inputs are thus remunerated, total product or national income would be 'exhausted'. If all inputs are homogeneous in a perfectly competitive environment and make the same contributions to output, then labour might earn on average an equitable reward. However, in reality the labour market is much more complex, and ownership and control of factors of production are not in the same hands. As labour is heterogeneous, it does have not the same quality even within the same occupation or industry. Differences in labour incomes arise partly from differences in human investment. Therefore, inequality in the personal distribution of income or in the relative share of labour and capital in national income is likely in any society (Barker, 2007).

The employment search theory as expounded by Trehan (2001) provides some useful insights as regards declining labour shares. Unemployed workers search for jobs until a wage offer presents itself. The worker will only accept a job offer where the wage offer is above his/her reservation wage. The worker becomes employed when there is a successful match between the worker's needs and that of the firm. If the average worker's reservation wage is significantly higher than the typical wage offer, then he/she will turn down such offers and continue searching for work, hence the unemployment rate will tend to be higher. Additionally, the wage offer made by a firm is dependent upon productivity: the higher the productivity (say an economy-wide boom due to business cycle upswing) the more attractive the wage offer (efficiency wage) made by firms in order to attract scarce or skilled labour, and this raises employment. Unemployment declines in response to increased productivity. This unemployment decline is unlikely to be permanent, when workers will come to realise that firms in general are offering higher wages than before. Consequently, labour will gradually adjust its reservation wage upwards. Thus, the unemployment rate will gradually adjust back to its original level. In light of the above, the high unemployment rate in South African can be explained by presuming that certain categories of skilled workers from formerly disadvantaged backgrounds have extremely high reservation wages. This is so partly because of the need to redress historical inequities and affirmative legislation. Further, the emergence of militant trade unions in alliance with the government, which now enjoy strong lobbying influence over government labour policies, serves to raise the reservation wage. Firms that enjoy monopolistic power due to industrial concentrations often respond to high wage demands by employing fewer workers producing at high productivity levels as compensation. Labour market conditions of this sort further promote offshoring to neighbouring states and make the employment of a higher complement of casual labour more attractive (Trehan, 2001; The Economist, 2012).

Mortensen and Pissarides (1998) considered the impact of technology on unemployment in a model that presumes that firms commit to existing technology when they create new jobs. However, due to technical progress, the technology linked with particular jobs becomes redundant over time. Hence firms have the choice to invest in upgrading the technology in the existing jobs, and this may entail retraining workers or destroying their jobs. The authors demonstrate that if technology upgrading costs are prohibitively high, then rapid technical progress makes existing technologies obsolete quicker, resulting in greater job destruction, notwithstanding the sectoral differences in updating technology. Aghion and Howitt (1998) 
support this perspective: they note that technological progress, despite sectoral variations, tends to destroy old jobs and at the same time it creates new ones. Moreover, they assert that if an increase in the pace of technological progress results in a rise in the rate of job destruction relative to the increase in the rate of job creation, this will result in a rise in the equilibrium unemployment rate. This displacement effect of technology is likely to perpetuate the disenfranchisement of labour's share of income.

Freeman (2005) observed that the opening of the Chinese, Indian and Russian economies since the 1990s doubled the world labour supply from approximately 1.46 billion workers to 2.92 billion. Since these economies possessed limited capital, the increase in the supply of labour contributed to dropping the world's capital to labour ratio by $40 \%$, thus decreasing the returns to labour while raising the returns to capital (Freeman, 2005). These stylised facts are also explained from a theoretical perspective by Anderson and Gascon (2007), who employ labour theory in conjunction with trade theory to demonstrate how offshoring (movement of production processes to low wage economies) results in increases in labour demand elasticities, thus leading to economic insecurities in relatively high-wage economies, and upsetting the income distribution.

An industry's wage demand for labour comprises two parts: the scale effect and the substitution effect. The scale effect measures the change in labour demand as a result of the wage rise due to change in output, while the substitution effect captures, for a given output level, how much firms substitute away from labour towards other factors of production, especially to capital, as a result of a wage increase. Anderson and Gascon (2007) expand the interpretation of the substitution effect to explain the process in which offshoring raises the labour demand elasticities in the high-wage (home) economy. They do so by invoking the ideas of Feenstra and Hanson $(1996,1999)$ to propose that international trade allows firms in high-wage economies to lower production costs by offshoring work to foreign businesses and importing intermediate inputs and finished goods. Hence, trade increases the factor substitution in response to higher wages beyond merely domestic non-labour factors. A higher degree of trade liberalisation tends to raise the elasticity of substitution.

Slaughter (2001) asserts that the mere potential threat of offshoring is sufficient to raise the elasticity of labour demand, without the firms actually engaging in offshoring. Moreover, Anderson and Gascon (2007) note that in highly automated production processes where labour cost is even a less important contributor to total costs, higher wages lead to larger adverse changes in quantity of labour demanded. The implication of higher labour demand elasticities is greater economic insecurities due to declining wage bargaining power, leading to slower wage growth and rising income inequality. In high-wage emerging economies like South Africa, apart from offshoring (as in the textile and leather industries moving to neighbouring African states) firms substitute permanent labour for casual labour, as well as introduce greater automation of production processes to curtail total costs (Keer, Wittenberg \& Arrow, 2014). Moreover, offshoring has taken on a new meaning in South Africa in that firms that cannot compete with low-wage economies might be shutting down (Government Report, 2009).

Milberg and Winkler (2009) outline the possible benefits of trade liberalisation and offshoring on labour demand and productivity increases in the home economy especially for skilled labour, and they also echo the effects of offshoring mentioned by Anderson and Gascon (2007). They stress that even though firms offshore production processes, they still retain in home countries their core competencies in finance, marketing, design and research and development. Consequently, they enjoy substantial returns stemming from efficiency gains which are reflected 
in the huge share of profits in the national income of the home country. On the downside, there is a fall in the rate of productive investment in the home country, with a concomitant rise in financial investments where quick and large profits are realised. This behaviour pattern by the non-financial corporate sector is known as financialisation due to the growing influence of financial markets and institutions on economic growth and development in both domestic and international markets (Milberg and Winkler, 2009).

Karabarbounis and Neiman (2013), after having closely studied 59 countries with data sets spanning at least 15 years, have documented that in a large majority of these countries - both developed and emerging market economies - the global labour share in income has declined significantly since the early 1980s. Piketty (2014) argues that when the rate of return on capital is greater than the rate of economic growth over the long run, the income and wealth of the capital owners grow faster than the income from labour and this inequality in distribution of wealth leads to a concentration of wealth among the top rich. Piketty and Saez (2006) gathered data on total income going to the top $10 \%$ of income earners in the USA back to 1913 . They found that starting in the mid-1980s the income share increased from $30 \%$ to almost $45 \%$ in 2002 .

Stockhammer, Onaran and Ederer (2009) noted that the pattern of the shift in the income distribution is quite varied. In the USA, for example, a sharp polarisation of personal income distribution has occurred, combined with a modest decline in the wage share, where the top $1 \%$ of earners (mainly managers) increased their income by more than $10 \%$ relative to the nonmanagerial income earners. Although in Europe the income distribution remained almost static, there has been an across-the-board reduction in incomes by about $10 \%$ over the past 15 years. The declining labour income share has come as a surprise to economists, for since the middle of the last century, due to the work of Kaldor (1957), the stability of labour income share has been a fundamental feature of macroeconomic models, which in turn determined the shape of the production function, inequality, and macroeconomic dynamics (Karabarbounis and Neiman, 2013).

According to Rodriguez and Jayadev (2010), the distribution of output between capital and labour has not been studied widely internationally. They stress that insights into this relationship are critical, on both normative and positive grounds. Under normative considerations, the knowledge of whether labour shares are declining or stable provides a comprehensive account of the evolution of income inequality over time, especially since these insights are not readily visible from microeconomic or household survey data compared to aggregate production function type assessments. This insight can help shed light on the structural and political economy factors that contribute to changes in interpersonal inequalities. With regard to the positive consideration, an empirical assessment of the relationship not only provides valuable information about the direction and magnitude of the changes, but also enables researchers to test existing theories and to develop new perspectives about dynamic macroeconomic relationships.

Synthesising the above ideas, the literature has identified a number of factors that have led to the decline in labour share relative to that of capital share. These include: the substitution of capital for labour due to the decline in the cost of capital with the advent and proliferation of computer technology, thus leading to exponential and varied synergic effects with the more traditional forms of technology (Karabarbounis and Nieman, 2013); increasing skill share of the labour force in the presence of capital-skill complementarity (Elsby, Hobijn \& Sahin, 2013); the off-shoring of labour-intensive aspects of production processes to economies that enjoy comparative advantages therein; the influence of financialisation - defined as the increasing 
role of financial motives and financial actors in the operation of economies and firms where shareholder value is of concern, causing funds being allocated to short-term, high-yielding financial investments and away from long-term low-yielding capital investments (Epstein, 2005); and the declining bargaining power of workers due to deunionisation and the concomitant rise in the centralised bargaining power of monopolistic firms (ILO, 2013).

\section{SOUTH AFRICAN LITERATURE REVIEW}

Although there have been numerous studies on labour issues in South Africa, to the best of our knowledge there is no recent published literature on the South African experience with declining labour share. Nonetheless, the factors mentioned above are likely to have similar effects on the South African labour share of income, as South Africa has long been integrated into the world economy. However, there might be circumstances unique to South Africa that are likely to enhance the propensity for substitution of capital for labour and contribute to a decline in labour-intensive industries (e.g., agribusiness, textile and leather) due to offshoring labour (Van Der Westhuizen, 2006). Bhorat and Hodge (1999) demonstrated that production changes have led to an increase in demand for skilled workers and a simultaneous decline for unskilled workers over the 1970-1995 period. This perspective is further reflected in the findings of Rodrik (2006) and Banerjee et al., (2008), where they recorded that the South African agriculture, mining and manufacturing sectors - the traditional highest employers of the country's unskilled labour - have suffered a relative decline, thus resulting in high unemployment levels among young, unskilled, predominantly black workers.

The impact of the apartheid legacy of an inferior education system for blacks reverberates right into the post-apartheid democratic governance, where the elected governments are still struggling to fill the structural education gaps (Biko, 2013). Klasen and Woolard (2005) recorded that poor initial education is a critical factor that reduces labour market access. Bhorat and Leibbrant (2001) revealed that the labour market participation rate is much lower for workers without a secondary education. Dias and Posel (2007) showed that the labour market participation rate increased with increased education levels; they demonstrated econometrically that workers with higher education levels had a significantly lower probability of being unemployed.

The Goldman Sachs Report (2013) noted that union membership in South Africa has increased by about $23 \%$ since 1994, to about 3 million members, of which COSATU commands a support base of 2 million members, and public sector membership has grown from $7 \%$ in 1994 to $39 \%$ by 2012 . Hence, the report concludes that the South African government shares both a political-alliance with the dominant trade union and an "intimate and complex employer relationship" with them as well. Greffrath (2014) asserts that the dominant influence of labour unions on the affairs of the state has resulted in labour-friendly policies, creating anti-employment wage biases. Kingdon and Knight (2008) noted that in the formal sector of the South African economy there is no market clearing of labour due to efficiency wage setting or due to union-determined labour wage setting, thus most of the formal sector pays well above the competitively determined market clearing wage rate level.

Moreover, South Africa's high real interest rate differential - interpreted as high-risk premiums arising from politico-economic vulnerabilities, encourages financialisation in the form of carry trade without the desirable long-term inflows that other BRICS members enjoy, which only serves to further exacerbate the employment problem and hence the declining labour share (Ashman 
and Pons-Vignon, 2014). According to Ashman et al. (2014), financialisation, in the form of local companies seeking short-term financial investments instead of long-term capital investments, increases due to labour-political risks or low real returns on long-term investment. They further add that a policy of high interest rate differential, as also existed in South Africa in recent years, stems from the need to attract funds due to large current account deficits born out of capital flight arising from liberalisation of exchange rates and credit-driven consumption of luxury-goods imports (Asman at al., 2014).

\section{COBB-DOUGLAS PRODUCTION FUNCTION}

The Cobb-Douglas functional form, incorporating labour, capital, and physical output, has traditionally been employed to study the relationship between the level of output and the quantities of inputs used. Although the Cobb-Douglas model provides a simplified view of the economy, especially when many other factors and inputs affect economic performance, this framework proved to be remarkably stable. The model assumes a multiplicative form of the economy, summarised in equation 1 below:

$$
Y=A K^{\beta_{1}} L^{\beta_{2}}
$$

where $Y$ represents output, while $K$ and $L$ denote capital and labour, respectively. Total factor productivity is measured by:

$$
A=\frac{Y}{K^{\beta_{1}} L^{\beta_{2}}}
$$

a scalar quantity which measures the real output per unit of input. Moreover, it is sometimes referred to as the level of technology in the economy that reflects the rate at which unit inputs are converted into output. The exponents $\beta_{1}$ and $\beta_{2}$ measure capital and labour shares of output, respectively. If the sum of these coefficients is unity, the property of constant returns to scale is indicated, and if this sum is greater than or less than unity, then increasing or decreasing returns are indicated, respectively.

\section{DATA AND METHODOLOGY}

This study used the yearly data on the number of workers employed in the formal sector data that Hodge (2009) compiled from various sources cited in his paper, over the 1946 to 2007 periods. Hodge looked at the employment coefficient in relation to economic growth. This paper updated the series to 2013, by averaging the quarterly data reported in various issues of the Quarterly Labour Force Surveys (QLFS) published by Statistics South Africa. Furthermore, the study used aggregate real GDP measured in 2005 constant prices to represent national income. Additionally, fixed capital formation was employed as an estimate of aggregate capital accumulation. The annual series for national income and capital were downloaded from the South African Reserve Bank website. All the mentioned series were transformed into natural logs (see equation 3 below) and were found to be I(I) non-stationary variables with positive trends and intercepts that were rendered stationary upon first differencing.

In order to examine the hypothesis that the labour share of income has been in decline in South Africa similar to the trends shown in advanced and emerging market economies, the study 
employed the Kalman $(1960,1963)$ filter technique within the state-space modelling framework (Commandeur \& Koopman, 2007). According to Van den Bossche (2011) and Cuthbertson et al., (1992) the Kalman filter is a commonly used approach to estimate the time-varying nature of regression coefficients as well as statistical models involving unobservable components. Equation 1, above, is transformed into the following log linearised version of the Cobb-Douglas production function:

$$
\ln Y_{t}=\beta_{0}+\beta_{1} \ln K_{t}+\beta_{2} \ln L_{t}+\varepsilon_{t}
$$

The paper follows the Inglesi-Lotz (2011) approach in the using the Kalman filter methodology of a multiplicative demand specification that is similar to the Cobb-Douglas equation 3 above. Specifically this paper uses the Kalman methodology to derive time-varying estimates of total factor productivity $\left(A=\ln \beta_{0}\right)$ as well as for capital $\left(\beta_{1}\right)$ and labour $\left(\beta_{2}\right)$ shares of national income (equation 3 above). In order to outline how these time-varying parameters are estimated, the study will first describe the general form of the state-space model via the use of matrix algebra (Commandeur and Koopman, 2007):

The observation or design equation:

$$
y_{t}=Z_{t}^{\prime} \alpha_{t}+\varepsilon_{t} \quad \varepsilon_{t} \sim N I D\left(0, \sigma_{\varepsilon}^{2}\right)
$$

The transition or measurement equation:

$$
\alpha_{t+1}=T_{t} \alpha_{t}+R_{t} \eta_{t} \quad \eta_{t} \sim N I D\left(0, Q_{t}\right)
$$

The lower-case term $y_{t}$ represents the natural log of national income and $\varepsilon_{t}$ is pure white noise and both the terms are scalars of the order $1 \times 1$. With regard to the rest of the matrices and vectors: $Z_{t}$ is an $m \times l$ observation or design vector, $T_{t}$ is an $m \times m$ transition matrix, $\alpha_{t}$ is an $m \times 1$ state vector, and $R_{t}$ is usually an identity matrix. However, in many models it is if the order $m \times r$ with $r<m$ and comprises the first $r$ columns of the identity matrix $I_{m}$. In this case $R_{t}$ is referred to as the selection matrix, for it selects the rows of the state equation which possess non-zero disturbance terms. Lastly, the $r \times l$ vector $\eta_{t}$ contains the $r$ state disturbances with zero means and unknown variances collected in an $r x r$ diagonal matrix $Q_{t}$. Now the study will define the vectors $Z_{t}, \alpha_{t}$ and $\eta_{t}$ and the matrices $T_{t}, R_{t}$ and $Q_{t}$ in order to derive the log linearised Cobb-Douglas production function as a special case of the state-space framework:

$$
\begin{gathered}
\alpha_{t}=\left(\begin{array}{l}
\beta_{0 t} \\
\beta_{1 t} \\
\beta_{2 t} \\
\lambda_{t}
\end{array}\right), \quad \eta_{t}=\left(\begin{array}{c}
\xi_{t} \\
\zeta_{t} \\
\zeta_{t} \\
v_{t}
\end{array}\right), \quad T_{t}=\left[\begin{array}{llll}
1 & 0 & 0 & 0 \\
0 & 1 & 0 & 0 \\
0 & 0 & 1 & 0 \\
0 & 0 & 0 & 1
\end{array}\right], \quad Z_{t}=\left(\begin{array}{c}
1 \\
k_{t} \\
l_{t} \\
D_{t}
\end{array}\right), \\
Q_{t}=\left[\begin{array}{cccc}
\sigma_{\xi}^{2} & 0 & 0 & 0 \\
0 & \sigma_{\zeta}^{2} & 0 & 0 \\
0 & 0 & \sigma_{\zeta}^{2} & 0 \\
0 & 0 & 0 & \sigma_{v}^{2}
\end{array}\right], \quad \text { and } \quad R_{t}=\left[\begin{array}{llll}
1 & 0 & 0 & 0 \\
0 & 1 & 0 & 0 \\
0 & 0 & 1 & 0 \\
0 & 0 & 0 & 1
\end{array}\right]
\end{gathered}
$$

In scalar notation the following model obtains (lower-case $y_{t}, k_{t}$ and $l_{t}$ represent natural logs of the variables, while $D_{t}$ represents the intervention or credit crunch dummy variable):

$$
y_{t}=\beta_{0 t}+B_{1 t} k_{t}+B_{2 t} l_{t}+\lambda_{t} D_{t}+\varepsilon_{t}, \quad \varepsilon_{t} \sim N I D\left(0, \sigma_{\varepsilon}^{2}\right)
$$




$$
\begin{gathered}
\beta_{0 t+1}=\beta_{0 t}, \quad \xi_{t} \sim N I D\left(0, \sigma_{\zeta}^{2}\right) \\
\beta_{1 t+1}=\beta_{1 t}, \quad \zeta_{t} \sim N I D\left(0, \sigma_{\zeta}^{2}\right) \\
\beta_{2 t+1}=\beta_{2 t}, \quad \zeta_{t} \sim N I D\left(0, \sigma_{\zeta}^{2}\right) \\
\lambda_{t+1}=\lambda_{t}
\end{gathered}
$$

Note $D_{t}$ assumes the value 1 for 2007 and 2009 , otherwise 0 , to accommodate for the unusually large errors that result without the inclusion of this intervention variable. In practice the state disturbance terms $\xi_{t}, \zeta_{t}, \varsigma_{t}$ and $v_{t}$ are usually set to zero in order to establish a stable relationship between the regressand and the regressors. This implies that the $\eta_{t}$ vector and the $Q_{t}$ and $R_{t}$ matrices all contain zeros; hence in scalar notation the above model reduces to the following, which this study estimates:

$$
\begin{gathered}
y_{t}=\beta_{0 t}+B_{1 t} k_{t}+B_{2 t} l_{t}+\lambda_{t} D_{t}+\varepsilon_{t}, \quad \varepsilon_{t} \sim N I D\left(0, \sigma_{\varepsilon}^{2}\right) \\
\beta_{0 t+1}=\beta_{0 t} \\
\beta_{1 t+1}=\beta_{1 t} \\
\beta_{2 t+1}=\beta_{2 t} \\
\lambda_{t+1}=\lambda_{t}
\end{gathered}
$$

In order to operationalise the above model for estimation via the use of the $\varepsilon$-views software the following notation is applied (Van den Bossche, 2011):

$$
\begin{gathered}
y_{t}=S V 1+S V 2 k_{t}+S V 3 l_{t}+S V 4 D_{t} \\
S V 1=c(2) S V 1(-1)+[\operatorname{var}=\exp (c 1)] \\
S V 2=S V(-1) \\
S V 3=S V(-1)
\end{gathered}
$$




$$
S V 4=S V(-1)
$$

Equation 8" specifies that the intercept term (total Factor Productivity) is allowed to vary stochastically over time, while equations 8" to 11 " demonstrate that the time-varying coefficients evolve deterministically through time in accordance with the assumption of a random-walk process. This assumption is necessary in order for the system to be identified (Pasricha, 2006).

The main purpose of the Kalman filter, which is a recursive algorithm, is to obtain optimal values of the state vectors at point $t$, using past observations up to $t$ - $l$; thereafter these predicted values are updated in accordance with incoming information at time $t$. Letting $s v_{t}$ (a shorthand notation of a matrix term representing any of the state vectors denoted by 8 " to 11 ") depicts a Kalman-filtered state at time $t$, thus the Kalman-filtered updating scheme can be represented as follows:

$$
S V_{t+1}=S V_{t}+K_{t}\left(y_{t}-Z_{t}^{\prime} \alpha_{t}\right)
$$

The value of $K_{t}$ in equation 12 is termed the Kalman gain; it determines how much the prediction error at time $t$ is allowed to influence the estimate of the state at $t+1$. The discrepancy term $\left(y_{t}-Z_{t}^{\prime} \alpha_{t}\right)$, ie., the difference between actual output and its estimate in each period, can be used to update the prediction of the state vector $\left(S V_{t+1}\right)$. Moreover, $K_{t}=\frac{P_{t}}{F_{t}}$, where $P_{t}$ denotes the filtered state estimation error variance, and $F_{t}$ the variance of the one-step ahead prediction errors $\left(v_{t}=\left(y_{t}-Z_{t}^{\prime} \alpha_{t}\right)\right)$. The prediction errors $\left(v_{t}\right)$ and their variances $\left(F_{t}\right)$ play a critical role in the maximisation of the log-likelihood function in the state-space methods. The Kalman gain may be interpreted as a simultaneous compromise between the (un)certainty of two phenomena amalgamated into one: when the uncertainty of the state based on past observations is high relative to the uncertainty of new observations at time $t$, then the value of $K_{t}$ will tend to one, thus enabling the incoming information to have a larger impact on the next value of the state. However, when the uncertainty of the new observation at $t$ is large compared to the uncertainty based on the past observations, then the value of $K_{t}$ tends to zero, thus preventing the new observations at time $t$ from having a significant impact on the next value of the state variable. When both (un)certainties cancel each other out, $K_{t}$ tends to 0.5 . Finally, the prediction errors $\left(v_{t}\right)$ and their variances $\left(F_{t}\right)$ are also instrumental in establishing whether the residuals of the state-space model are independently (no autocorrelation), identically (homoscedastic) and normally distributed. This study conducts these tests in order to establish the validity of the model.

\section{RESULTS AND DISCUSSION}

The output of the Cobb-Douglas production function, TABLE 2 in the Appendix, shows that the model has been fitted on 68 observations using the Marquardt optimisation algorithm. The $\varepsilon-$ views software needed 15 iterations to achieve convergence. At convergence the maxim log likelihood is found to be 126.55. The statistically significant coefficients $C(1)$ and $C(2)$ represents the constant parameters of the estimation; SVI can be interpreted as the Solow residuals that represent total factor productivity, also known as the technology factor. SV2 and SV3 represent labour and capital changes respectively. Furthermore, the diagnostic tests confirm that the model is well specified: in particular, the model's residuals tend to exhibit an approximate normal distribution, as confirmed by the Jacque-Bera statistic, which is 1.76 with a 
$p$-value of .4l (see FIGURE 2, Appendix) and skewness and kurtosis are not a problem; the $\ell$ statistics at all lags are high (exceeding their corresponding Chi critical static at conventional levels) with high $p$-values, thus indicating the residuals are not autocorrelated (TABLE 4 in Appendix); Park's tests for heteroscedasticity confirm that the residuals are homoscedastic (TABLE 5 in Appendix).

Figure 1: Estimate Structural Vectors
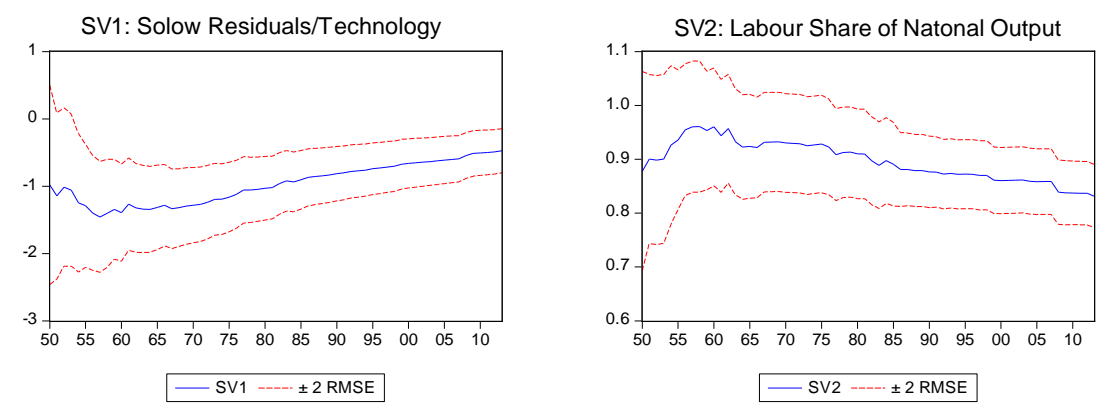

SV3: Capital Share of National Output

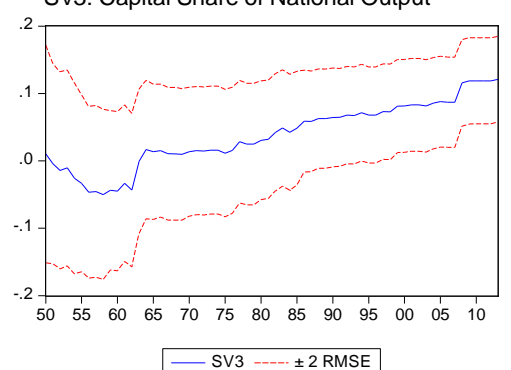

An inspection of FIGURE 1 (SV2) clearly shows that labour share of income has been on a declining long-run trend, especially since the 1960s, while that of capital (SV3) has been on a rising long-run trend. Thus the South African experience is consistent with that of many developed and emerging economies, and to a certain extent it is in line with the findings of Piketty. The literature review identified possible reasons for this phenomenon, some of which South Africa shares with other economies, while others might be unique to South Africa's historical and socio-political phenomena. The estimated shares contained in the graphs of the state vectors of FIGURE 1 span the entire 1946-2013 period. For the purposes of providing a closer inspection of the changing factor shares of income over recent times, TABL 3 captures the actual numerical shares extracted from FIGURE 1, over the 1980-2013 period.

TABLE 3 demonstrates the worrying finding that the labour share of income declined by $7 \%$, from a high of $91 \%$ in 1980 to $83 \%$ in 2013 , while the capital share of income increased from $3.1 \%$ in 1980 to $12.1 \%$ in 2013 . The decline in labour share appears to be much higher than in the context of international studies, where the net decline was in the region of $4 \%-4.5 \%$. 
DECLINING LABOUR SHARE OF INCOME IN SOUTH AFRICA: THE KALMAN FILTER APPROACH

TABLE 3: Estimates of TFP, Labour and Capital Shares 1980-2013

\begin{tabular}{|c|c|c|c|c|}
\hline Date & LTFP & L-Share & K-Share & TFP \\
\hline 1980 & -1.0309 & 0.909902 & 0.030536 & 0.356685 \\
\hline 1981 & -1.02154 & 0.909719 & 0.032118 & 0.360042 \\
\hline 1982 & -0.9621 & 0.897137 & 0.04216 & 0.382088 \\
\hline 1983 & -0.92159 & 0.888808 & 0.048811 & 0.397888 \\
\hline 1984 & -0.93778 & 0.897488 & 0.042331 & 0.391498 \\
\hline 1985 & -0.90587 & 0.890682 & 0.048515 & 0.404192 \\
\hline 1986 & -0.86952 & 0.880842 & 0.058753 & 0.419153 \\
\hline 1987 & -0.85755 & 0.881138 & 0.05850 & 0.424202 \\
\hline 1988 & -0.84531 & 0.878936 & 0.062704 & 0.429425 \\
\hline 1989 & -0.8326 & 0.878935 & 0.062612 & 0.434918 \\
\hline 1990 & -0.81385 & 0.876575 & 0.064248 & 0.443149 \\
\hline 1991 & -0.80104 & 0.876183 & 0.064595 & 0.448862 \\
\hline 1992 & -0.78099 & 0.872254 & 0.067797 & 0.457955 \\
\hline 1993 & -0.77313 & 0.873765 & 0.067191 & 0.461566 \\
\hline 1994 & -0.76072 & 0.871851 & 0.071477 & 0.46733 \\
\hline 1995 & -0.74084 & 0.872276 & 0.067812 & 0.476711 \\
\hline 1996 & -0.73022 & 0.872232 & 0.068037 & 0.481802 \\
\hline 1997 & -0.71527 & 0.870074 & 0.07307 & 0.489059 \\
\hline 1998 & -0.70459 & 0.87010 & 0.072628 & 0.494314 \\
\hline 1999 & -0.6748 & 0.86093 & 0.081309 & 0.509257 \\
\hline 2000 & -0.66305 & 0.860365 & 0.081488 & 0.515278 \\
\hline 2001 & -0.65273 & 0.86079 & 0.083056 & 0.520623 \\
\hline 2002 & -0.64386 & 0.861082 & 0.083024 & 0.525262 \\
\hline 2003 & -0.63446 & 0.861723 & 0.081388 & 0.530223 \\
\hline 2004 & -0.62187 & 0.859302 & 0.085563 & 0.53694 \\
\hline 2005 & -0.61192 & 0.858293 & 0.087799 & 0.542308 \\
\hline 2006 & -0.60269 & 0.858552 & 0.08708 & 0.547339 \\
\hline 2007 & -0.5938 & 0.858552 & 0.08708 & 0.552225 \\
\hline 2008 & -0.54488 & 0.838727 & 0.115678 & 0.579912 \\
\hline 2009 & -0.51415 & 0.837524 & 0.11866 & 0.59801 \\
\hline 2010 & -0.50635 & 0.837338 & 0.118801 & 0.602692 \\
\hline
\end{tabular}




\begin{tabular}{lllll}
\hline 2011 & -0.49850 & 0.837024 & 0.118831 & 0.60744 \\
2012 & -0.49107 & 0.836656 & 0.118687 & 0.611974 \\
2013 & -0.47417 & 0.831348 & 0.121094 & 0.62240 \\
\hline
\end{tabular}

Source: Authors' analysis

Total factor productivity, (SV1) on the other hand, has been on a positive trend since 1957; hence a combination of a rise in capital share and a trend increase in total factor productivity makes up for the decline in labour productivity. The contributory share of total factor productivity, a scalar which measures the real output per unit of input, increased from 0.35 in the 1980 to 0.46 in 1994, a $31 \%$ increase, and continued to increase even during the postapartheid period.

This clearly reflects that capital and 'residual factors' are making a progressively greater contribution to growth in income than labour. These findings may further indicate that since the early 1990s the economy has undergone significant structural changes in the nature and form of the production process and in the labour market. Although the total number of people employed has increased over the 1946-2013 period, the growth rate of effective labour employed has been on a declining trend. As shown in TABLE 6, Appendix, the labour growth rate has been declining by $3.1 \%$ per annum; the coefficient is significant at the $10 \%$ significance level. Hence within the context of the Cobb-Douglas framework the only major contender to explain the consistent expansion of the economy in the post-apartheid era is attributable to TFP.

The post-1990s phenomenal rise in TFP implies that the South African economy has been shifting to technologically intensive production processes complemented by the utilisation of highskilled labour. At the same time, the South African economy has been experiencing some form of de-industrialisation in recent decades (van Aardt, 2009). The share of employment in the manufacturing sector and the latter's contribution to South Africa's GDP has been on a declining trend, while that of the services or tertiary sector, as in more developed countries, is on the rise (Altman, 2013). The share of manufacturing to South Africa's GDP has declined from $17.5 \%$ in 2006 to $12 \%$ in 2013 , while that of the service sector increased from $65.9 \%$ to $70 \%$ during the same period (SARB, 2014). It is the manufacturing sector that tends to be labour-intensive, absorbing many semi-skilled and unskilled workers in larger firms; it also exhibits economies of scale (van Aardt, 2009; Keer, Wittenberg and Arrow, 2014). It is noteworthy that this process parallels the rise of dominance of trade unions in determining the directions of wages in the South African economy and its power to lobby the authorities into adopting its preferred policies. This is contrary to the world experience, where trade union bargaining power and its capacity to influence policy is diminishing.

\section{POLICY SUGGESTIONS AND CONCLUSION}

The study has demonstrated via the Kalman filter methodology that labour and capital shares have been moving in opposite directions in the last 68 years, thereby giving rise to a skewing distribution of income and wealth. Technical change, globalisation and structural changes as well as labour legislation have changed the skills requirements and earnings share of labour and capital. Technology has also shifted activity from rich to poorer countries (offshoring) and shifted power to employers, thereby contributing to a decrease in the labour share of income (Coyle, 2012). Widening inequality slows the pace of growth and can heighten social instability. 
These findings are a cause for concern in a politically sensitive economy like South Africa, where unemployment, presently at over $25 \%$, and youth unemployment, presently at over $50 \%$, is on a rising trend. The results suggest that inequality in the distribution of market income is widening, and accompanying this development there is a rising concentration of wealth among the capitalists and top income earners. According to Piketty (2014), rising inequality in the distribution of income leads to a form of patrimonial capitalism, driven by rich resource owners, households and corporates.

If one accepts Piketty's reasoning, then a low economic growth rate, as is the case presently in South Africa, might create fewer employment opportunities and thereby worsen inequalities. Unchecked, this scenario might endanger social cohesion and lead to political instability, signs of which are already apparent, with rising number of protests against service delivery failures in South Africa (The Economist, 2012). However, the diminishing marginal productivity theory applied to capital suggests that it may be even harder to earn high returns on wealth or capital the more there is of it.

To counteract the growth in income share of capital and enhance the share of labour, Piketty suggests a global tax on wealth. In South Africa the middle class is already heavily taxed. Further increases in tax might not be a desirable policy, as we have too few taxpayers (about 6.4 million) relative to the number of individuals depending on the state grants redistribution policy (about 15 million) and the tax burden is already too high (Budget Review, 2014). According to a Grant Thornton study South Africa's highest tax bracket, from $29 \%$ to $40 \%$, is significantly higher than the current global average top marginal rate at about $29 \%$. The study indicates that of South Africa's 5.7 million taxpayers to cover for a population of about 50 million people, about 2.75 million carry $64 \%$ of the personal income tax burden (Peacock, 2011). Higher taxation of the rich might lead to a migration of capital, talents and entrepreneurship, much needed to provide greater employment and income opportunities to labour. Attacking capital is likely to worsen the plight of labour and poor individuals. However, developing a culture of fairness in the distribution of rewards to labour may be necessary, as certain members are perceived to be earning 'greed' salaries with incomes as high as more than a 100 times those of low-paid labour (Coyle, 2012).

More opportunities should be created for labour, especially the youth, to advance through enhanced capabilities and relevant education, to earn an income through employment. This means that the environment for labour absorption should be attractive. But the labour relations environment is regarded as adversarial in South Africa, forcing employers to substitute capital for labour in production (Parsons, 2013). Indeed, according to the World Economic Forum's 2014/2015 Global Competitiveness Report (GCl), South Africa's rank declined to $56^{\text {th }}$ position (out of 144 countries) compared to $50^{\text {th }}$ position in 2011 . The $\mathrm{GCl}$ report also indicates that labour market efficiency (ranked $113^{\text {th }}$ ) is affected by extremely rigid hiring and firing practices $\left(143^{\text {rd }}\right)$, wage inflexibility $\left(139^{\text {th }}\right)$ and continuing significant tensions in labour-employment relations $\left(144^{\text {th }}\right)$ in South Africa. Against this background, raising education standards to improve productivity, income and employability of labour in South Africa and making its labour market more efficient and flexible are critical for enhancing competitiveness and labour share of income (GCl, 2014/15). To augment workers' share and bridge the inequality gap, labour has to possess better skills and deliver on productivity.

Many of the NDP policy suggestions aimed at enhancing economic and employment rates and reducing inequality, hence increasing labour share, need to be pursued more vigorously. These include enhanced investment in education and use of the transfer system of social spending 
that enhances labour employment and income growth. Other policies that need to be enacted include the implementation of the youth employment subsidies on a sustained medium-term basis; more flexible labour policies with wage rates being linked to inflation and firm-level productivity increases, and decentralisation of wage-bargaining processes, especially in respect of small, medium and micro enterprises that are struggling to gain a foothold in the South African economy. These measures, hopefully, will assist more people to gain employment, spur economic growth and increase the share of labour in the national cake. It is desirable that more light be shed by future studies on the trends and causes of declining labour shares.

\section{LIST OF REFERENCES}

Acemoglu, D. \& Robinson, J. A. (2012). Why Nations Fail: The Origins of Power, Prosperity and Poverty, Crown Business, New York.

Adam, T., Benecka, S., \& Jansky, I. (2012). Time-Varying Betas of Banking Sectors,

Czech Journal of Economics and Finance, 62 (6). pp. 485-504.

Aghion, P. \& Howitt, P. (1998). Endogenous Growth Theory. Cambridge: MIT Press.

Altman, M. (2013): The Challenge of Employment Creation in South Africa. In Pillay, U.

Hagg, G. \& Nyamnjoh, F. (eds.) State of the Nation South Africa 2012-2013. Ed HSRC Press, Pretoria (pp. 185-221).

Anderson, R.G. \& Gascon, C.S. (2007). The Perils of Globalisation: Offshoring and Economic Insecurity of the American Worker, Federal Reserve Bank of St. Louis Working Paper Series. Working Paper No. 2007-004A king Paper 2007-004A. Available: http://research.stlouisfed.org/wp/2007/2007-004.pdf

Ashman, S. \& Pons-Vignon, N. (2014). NUMSA rupture could mark new start for socialist politics. Business Day. Tuesday 11 February 2014, p. 9

Banerjee, A., Galiani, S., Levinsohn, J. \& Woolard, I. (2006). Why has unemployment risen in the new South Africa? Working Paper 134, Centre for International Development (CID), Harvard University.

Barker, F. (2007). The South African Labour Market. Pretoria: Van Schaik.

Bhorat, H. \& Hodge, J. (1999). Decomposing shifts in labour demand in South Africa. South African Journal of Economics, 67(3), pp. 348-380.

Bhorat, H. \& Leibbrandt, M. (2001). Modelling vulnerability and low earnings in the South African labour market. In Bhorat, H. (ed.) Fighting Poverty-labour markets and inequality in South Africa. Cape Town: UCT Press.

Biko, H. (2013). The Great African Society. Cape Town: Jonathan Ball Publishers.

Budget Review (2014). Budget Speech. National Treasury, Pretoria: Government Printer.

Commandeur, J.F. \& Koopman, S.J. (2007). Practical Econometrics: An Introduction to Sate Space Time Series Analysis. New York: Oxford University Press.

Coyle, D. (2012). The Economics of Enough. Princeton: Princeton University Press.

Cuthbertson, K., Hall, S. \& Taylor., M.P. (1992). Applied Econometrics Techniques. Harvester Wheatsheaf, New York, USA. 
Dias, R. \& Posel, D. (2007). Unemployment, Education and Skills Constraints in Post-Apartheid South Africa. (Working Paper Series by the Development Policy Research Unit, March 2007 (pp. 1-38).

Elsby, M.W.L., Hobijn, B. \& Sahin, A. (2013). The Decline of the U.S. Labour Share, Brookings Panel on Economic Activity, September 19-20, 2013. pp. 1-45

Epstein, G.A. (2005). Financialization and the World Economy. Cheltenham, UK: Edward Elgar Publishing.

Feenstra, R.C. \& Hanson, G.H. (1996). Globalization, Outsourcing, and Wage Inequality. American Economic Review, 86(2), pp. 240-245.

Feenstra, R.C. \& Hanson, G.H. (1999). The Impact of Outsourcing and High-Technology Capital on Wages: Estimates for the United States, 1979-1990. The Quarterly Journal of Economics, 114(3). pp. 907-940.

Freeman, R. (2005). The Great Doubling: Labor in the New Global Economy. Usury Lecture in Labor Policy, Georgia State University, April.

Greffrath, W. (2014). Developmental state: government lacks autonomy to emulate Asian Tigers' path. Business Day. Wednesday, 22 January 2014, p. 9.

Global Competitiveness Report 2014-2015 (2014). World Economic Forum, Geneva, Switzerland.

Goldman Sachs Report (2013). Two Decades of Freedom: What South Africa is doing with it and what it now needs to do with it. Goldman Sachs Report released 4 November 2013

Government Report (2009). The performance of the South African Economy. The DTI Annual Report 2008/9, Pretoria: Government Printer.

Hodge, D. (2009). Growth, Employment and Unemployment in South Africa. South African Journal of Economics, 77(4), pp. 488-504.

Inglesi-Lotz, R. (2011). The Evolution of Price Elasticity of Electricity Demand in South Africa: A Kalman Filter Application. Energy Policy, 39, pp. 3690-3696.

International Labour Organisation (ILO) (2013). Global Employment Trends: Recovering from a Second Jobs Dip. International Labour Organisation Report, January 2013.

International Monetary Fund (IMF), (2010). Unemployment dynamics during recessions and recoveries: Okun's Law and beyond, Chapter 3 in IMF, World Economic Outlook: Rebalancing Growth, April 2010. Washington, D.C: IMF.

Kaldor, N. (1957). A Model of Economic Growth. The Economic Journal, 67(4), pp. 591-624.

Kalman, R.E. (1960). A New Approach to Linear Filtering and Prediction Problems. Journal of Basic Engineering, 82(1), pp. 35-45.

Kalman, R.E. (1963). New Methods in Wiener Filtering Theory. In: Proceedings of the First Symposium of Engineering Applications of Random Function Theory and Probability, p.270.

Karabarbounis, L. \& Neiman, B. (2013). The global decline of the labour share. NBER Working Papers 19136, National Bureau of Economic Research.

Keer, A., Wittenberg, M. \& Arrow, J. (2014). Job Creation and destruction in South Africa. South African Journal of Economics, 82(1), pp 1-18.

Kingdon, G.G. \& Knight, J. (2008). Unemployment: South Africa's Achilles' heel. In J. Aron, B. Kahn and G. Kingdon. South African Economic Policy under democracy. Oxford: Oxford University Press. 
Klasen, S. \& Woolard, I. (2005). Determinants of income mobility and household poverty dynamics in South Africa. Journal of Development Studies, 41(5), pp. 865-897.

Maddala, G. (1992). Introduction to Econometrics, $2^{\text {nd }}$ edition. New York: Macmillan.

Milberg, W. \& Winkler, D. (2010). Financialisation and the Dynamics of Offshoring in the USA. Cambridge Journal of Economics, 34(2), pp. 275-293.

Mortensen, D.T. \& Pissarides, C.A. (1998). Technological Progress, Job Creation, and Job Destruction. Review of Economic Dynamics, pp. 733-753.

OECD (2012). Labour Losing to Capital: What Explains the Declining Labour Share? OECD Employment Outlook 2012, 0ECD Publishing.

Parsons, R. (2013). Zumanomics Revisited. Johannesburg: Jacana.

Peacock, B. (2011). Bleeding Us Dry, Sunday Times, 28 November.

Picketty, T. (2014). Capital in the Twenty-First Century. Princeton: Harvard University Press.

Picketty, T. \& Saez, ع. (2006). The Evolution of Top Incomes: A Historical and International

Perspective. Cambridge MA: National Bureau of Economic Research. (Working Paper No. 11955).

QFLS (2000-2013). Various Issues Quarterly Labour Force Surveys, Statistics South Africa. Pretoria.

Rodrik, D. (2006). Understanding South Africa's economic puzzles. CID, Harvard University. (Working Paper 130).

Rodriguez, F. \& Jayadev, A. (2010). The Declining Labor Share of Income, Human Development Research Papers (2009 to present) HDRP-2010-36, Human Development Report Office (HDRO), United Nations Development Programme (UNDP).

SARB (2014). South African Reserve Bank Quarterly Bulletin, March, No. 271, Pretoria.

Slaughter, M.J. (2001). International Trade and Labor-Demand Elasticities. Journal of International Economics, 54(1), pp 27-56.

Stockhammer, E., Onaran, 0. \& Ederer, S. (2009). Functional income distribution and aggregate demand in the Euro area. Cambridge Journal of Economics, 33(1), pp. 139-159.

The Economist (2012). Over the Rainbow, 20, October, pp. 22-24.

Trehan, B. (2001). Unemployment and Productivity. Federal Reserve Bank of San Francisco Economic Letter. October Issue 12, pp. 1-4.

Van Aardt, C. (2009). Labour policy and Job Creation: Too many Holy Cows? In Parsons, R.

Zumanomics, Johannesburg: Jacana, pp 129-147.

Van den Bossche, F.A.M. (2011). Fitting State Space Models with Eviews. Journal of Statistical Software, $41(8)$, pp. 1-16.

Van Der Westhuizen, C. (2006). Trade and Poverty: A Case Study of the South African Clothing Industry Trade and Poverty Project. Southern African Labour and Development Research Unit. Available from: http://www.saldru.uct.ac.za/saldru_trade\&poverty.html (Accessed 28 January 2014). 


\section{APPENDIX}

\begin{tabular}{|c|c|c|c|}
\hline \multicolumn{4}{|c|}{$\begin{array}{l}\text { Sample: } 19462013 \text {. } \\
\text { Included observations: } 68 \\
\text { Breakpoint variables: C Ln_Labour, Ln_Capital } \\
\text { Break test options: Trimming } 0.15 \text {, Max. breaks } 5 \text {, Sig. level } \\
\quad 0.05\end{array}$} \\
\hline \multicolumn{3}{|c|}{ Sequential F-s tatistic determ ined breaks: } & 3 \\
\hline Break Test & F-s ta tis tic & $\begin{array}{l}\text { Scaled } \\
\text { F-statis tic }\end{array}$ & $\begin{array}{l}\text { Critical } \\
\text { Value." }\end{array}$ \\
\hline 0 vs. $1^{*}$ & 56.67934 & 170.0380 & 13.98 \\
\hline 1 vs. $2^{\circ}$ & 19.93267 & 59.79800 & 15.72 \\
\hline 2 vs. $3^{-}$ & 5.877770 & 17.63331 & 16.83 \\
\hline 3 vs. 4 & 2.803190 & 8.409570 & 17.61 \\
\hline \multirow{3}{*}{\multicolumn{4}{|c|}{$\begin{array}{l}\text { - Significant at the } 0.05 \text { level. } \\
\text { - Bai-Perron (Econometric Journal, } 2003 \text { ) critical values. }\end{array}$}} \\
\hline & & & \\
\hline & & & \\
\hline 1 & 1991 & 1963 & \\
\hline 2 & 1983 & 1991 & \\
\hline 3 & 2001 & 2001 & \\
\hline
\end{tabular}

\begin{tabular}{|c|c|c|c|c|}
\hline \multicolumn{5}{|c|}{$\begin{array}{l}\text { Method: Maximum like lihood (Marquardt) } \\
\text { Sample: } 19462013 \\
\text { Included observations: } 68 \\
\text { Convergence achieved after } 15 \text { iterations }\end{array}$} \\
\hline & Coefficient & Std. Error & $z-S$ ta tis tic & Prob. \\
\hline$c(1)$ & -7.799914 & 0.159334 & -48.95309 & 0.0000 \\
\hline \multirow[t]{2}{*}{$\mathrm{c}(2)$} & 0.985257 & 0.007224 & 136.3842 & 0.0000 \\
\hline & Final State & Root MSE & $z-S$ ta tis tic & Prob. \\
\hline sv1 & -0.467181 & 0.162594 & -2.873289 & 0.0041 \\
\hline sv2 & 0.831348 & 0.029243 & 28.42939 & 0.0000 \\
\hline sv 3 & 0.121094 & 0.031834 & 3.803959 & 0.0001 \\
\hline $\mathrm{sv} 4$ & -0.052788 & 0.010344 & -5.103210 & 0.0000 \\
\hline Log likelihood & 126.5466 & \multicolumn{2}{|c|}{ Akaike info criterion } & -3.663134 \\
\hline Param eters & 2 & \multicolumn{2}{|c|}{ Sohwarz criterion } & -3.597854 \\
\hline Diffuse priors & 4 & $H$ annan- $Q$ & inn criter. & -3.637268 \\
\hline
\end{tabular}

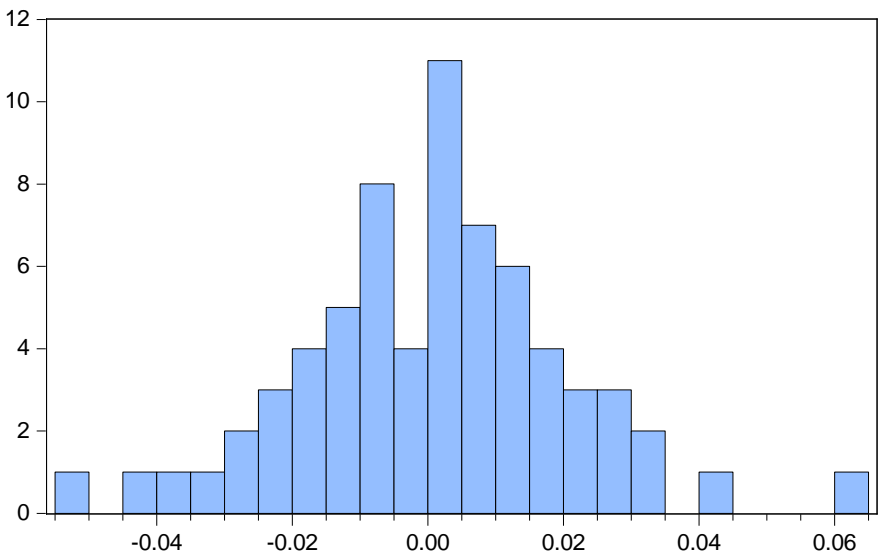

Series: DISTURBANCE

Sample 19462013

Observations 68

Mean $\quad 0.000927$

Median $\quad 0.001701$

Maximum $\quad 0.061140$

Minimum $\quad-0.052106$

Std. Dev. $\quad 0.019759$

Skewness $\quad 0.035859$

Kurtosis $\quad 3.785797$

Jarque-Bera $\quad 1.764090$

Probability $\quad 0.413936$

FIGURE 2: Residuals Normality Test

\section{TABLE 4: Residuals Autocorrelation Test}

Sample: 19462013

Included observations: 68

\begin{tabular}{|c|c|c|c|c|c|c|}
\hline Autocorrelation & Partial Correlation & & $A C$ & PAC & Q-Stat & Prob \\
\hline.$|*|$. &.$|*|$. & 1 & 0.113 & 0.113 & 0.9120 & 0.340 \\
\hline.$*||$. & $. * 1 . \mid$ & 2 & -0.163 & -0.178 & 2.8308 & 0.243 \\
\hline .1 .1 &.$|*|$. & 3 & 0.069 & 0.116 & 3.1770 & 0.365 \\
\hline .1 .1 &.$||$. & 4 & 0.006 & -0.052 & 3.1798 & 0.528 \\
\hline.$*||$. & .1 .1 & 5 & -0.090 & -0.054 & 3.7935 & 0.580 \\
\hline .1 .1 & .1 .1 & 6 & -0.023 & -0.018 & 3.8353 & 0.699 \\
\hline.$|*|$. &.$|*|$. & 7 & 0.117 & 0.106 & 4.9079 & 0.671 \\
\hline
\end{tabular}

Journal of Economic and Financial Sciences / JEF / July 2015 8(2), pp. 372-391 


\begin{tabular}{|c|c|c|c|c|c|c|}
\hline .1 .1 &.$||$. & 8 & -0.033 & -0.065 & 4.9927 & 0.758 \\
\hline.$*||$. &.$\star||$. & 9 & -0.179 & -0.135 & 7.5902 & 0.576 \\
\hline .1 .1 & .1 .1 & 10 & -0.010 & -0.003 & 7.5987 & 0.668 \\
\hline .1 .1 & .1 .1 & 11 & -0.001 & -0.048 & 7.5989 & 0.749 \\
\hline .1 .1 & .1 .1 & 12 & -0.037 & 0.006 & 7.7166 & 0.807 \\
\hline .1 .1 & .1 .1 & 13 & -0.034 & -0.050 & 7.8147 & 0.855 \\
\hline .1 .1 & .1 .1 & 14 & 0.006 & -0.017 & 7.8183 & 0.899 \\
\hline.$\star||$. &.$*||$. & 15 & -0.160 & -0.189 & 10.126 & 0.812 \\
\hline.$*||$. & .1 .1 & 16 & -0.105 & -0.029 & 11.136 & 0.801 \\
\hline.$|*|$. & .1 .1 & 17 & 0.096 & 0.048 & 12.005 & 0.800 \\
\hline .1 .1 & .1 .1 & 18 & 0.010 & -0.039 & 12.014 & 0.847 \\
\hline.$*||$. &.$\star||$. & 19 & -0.148 & -0.143 & 14.130 & 0.776 \\
\hline .1 .1 &.$\star \star||$. & 20 & -0.057 & -0.077 & 14.457 & 0.807 \\
\hline .1 .1 & .1 .1 & 21 & 0.051 & 0.004 & 14.720 & 0.837 \\
\hline .1 .1 & .1 .1 & 22 & -0.019 & -0.013 & 14.756 & 0.872 \\
\hline .1 .1 &.$|*|$. & 23 & 0.059 & 0.083 & 15.121 & 0.890 \\
\hline.$|*|$. & .1 .1 & 24 & 0.148 & 0.024 & 17.502 & 0.826 \\
\hline .1 .1 &.$*||$. & 25 & -0.038 & -0.092 & 17.658 & 0.857 \\
\hline.$\star||$. & $. \star 1 . \mid$ & 26 & -0.125 & -0.080 & 19.427 & 0.818 \\
\hline .1 .1 & .1 .1 & 27 & -0.027 & -0.039 & 19.514 & 0.851 \\
\hline .1 .1 & .1 .1 & 28 & 0.033 & -0.028 & 19.644 & 0.877 \\
\hline
\end{tabular}

\section{TABLE 5: Park Test for Heteroscedasticity}

Dependent Variable: ERRORSQUARED

Method: Least Squares

Sample: 19462013

Included observations: 68

\begin{tabular}{lrcrr}
\hline \hline \multicolumn{1}{c}{ Variable } & Coefficient & Std. Error & t-Statistic & Prob. \\
\hline \multicolumn{1}{c}{ C } & 0.008449 & 0.011542 & 0.732055 & 0.4668 \\
InLabour & -0.000753 & 0.001061 & -0.709740 & 0.4804 \\
InCapital & 0.000323 & 0.000459 & 0.703282 & 0.4844 \\
\hline \hline R-squared & 0.007744 & Mean dependent var & & 0.000386 \\
Adjusted R-squared & -0.022787 & S.D. dependent var & 0.000649 \\
S.E. of regression & 0.000656 & Akaike info criterion & & -11.77780 \\
Sum squared resid & $2.808-05$ & Schwarz criterion & -11.67988 \\
Log likelihood & 403.4451 & Hannan-Quinn criter. & -11.73900 \\
F-statistic & 0.253647 & Durbin-Watson stat & & 1.690098 \\
Prob(F-statistic) & 0.776730 & & \\
\hline \hline
\end{tabular}




\section{TABLE 6: Labour Growth Trends RegressionT}

Dependent Variable: LABOUR_GROWTH

Method: Least Squares

Sample: 19472013

Included observations: 67

\begin{tabular}{lrcrr}
\hline \hline \multicolumn{1}{c}{ Variable } & Coefficient & Std. Error & t-Statistic & Prob. \\
\hline \multicolumn{1}{c}{ C } & 2.683172 & 0.642374 & 4.176966 & 0.0001 \\
\multicolumn{1}{c}{ TREND } & -0.030713 & 0.016423 & -1.870143 & 0.0660 \\
\hline \hline R-squared & 0.051059 & Mean dependent var & 1.638944 \\
Adjusted R-squared & 0.036460 & S.D. dependent var & 2.648380 \\
S.E. of regression & 2.599651 & Akaike info criterion & 4.778028 \\
Sum squared resid & 439.2822 & Schwarz criterion & 4.843840 \\
Log likelihood & -158.0639 & Hannan-Puinn criter. & 4.804070 \\
F-statistic & 3.497434 & Durbin-Watson stat & & 1.927778 \\
Prob(F-statistic) & 0.065968 & & \\
\hline \hline
\end{tabular}

